\title{
Effect of vigabatrin on striatal dopamine receptors: evidence in humans for interactions of GABA and dopamine systems
}

\author{
H A Ring, M R Trimble, D C Costa, M S George, P Verhoeff, P J Ell
}

Raymond Way Neuropsychiatry Research Group, Institute of Neurology, London

H A Ring

M R Trimble

M S George Medicine, University Hospital School of Medicine, London D C Costa

P J Ell

Cygne BV, Technical University, Eindhoven, The Netherlands $P$ Verhoeff

Correspondence to: Dr Ring, Institute of London WCIN 3BG, UK.

*Department of Psychiatry and Behavioural Sciences, Medical University of South USA

Received 1 November 1991 and in revised form 6 January 1992

Accepted 13 January 1992
Institute of Nuclear College and Middlesex Neurology, Queen Square, Carolina, Charleston, SC,

\begin{abstract}
Vigabatrin is a specific $\gamma$-aminobutyric acid transaminase inhibitor. The clinical use of this drug in the treatment of epilepsy has been sporadically linked to the development of psychosis. Using ${ }^{123}$ I-IBZM, a specific dopamine D2 receptor ligand and single photon emission tomography (SPET), one month of treatment with vigabatrin was associated with a decrease in specific binding of ${ }^{123} I-I B Z M$ to $\mathrm{D2}$ receptors in the left hemisphere basal ganglia. This change may provide one explanation for the development of psychosis in vulnerable patients.
\end{abstract}

\section{(F Neurol Neurosurg Psychiatry 1992;55:758-761)}

Vigabatrin is a new anticonvulsant drug with proven efficacy in patients with intractable epilepsy. ${ }^{1}$ It acts to inhibit $\gamma$-aminobutyric acid (GABA)-transaminase, the enzyme responsible for GABA catabolism, and has been shown in vivo to increase brain and CSF GABA concentrations. $^{2-4}$ The clinical use of vigabatrin has, as an uncommon side effect, been associated with the development of psychotic states reversible on reducing or withdrawing the treatment. ${ }^{56}$

Experimental studies have suggested that an important site of action at which enhanced GABAergic activity exerts an anticonvulsant effect by inhibiting seizure propagation is the substantia nigra. $^{7}$ The substantia nigra pars compacta is the site of origin of the great majority of dopamine efferents to the limbic and sensorimotor striatum. ${ }^{8}$ Overactivity in dopaminergic systems is thought to contribute to the development of psychotic mental states. The aim of this study was to investigate interactions between nigrostriatal GABA and

Table 1 Patient characteristics

\begin{tabular}{|c|c|c|c|c|c|c|}
\hline \multirow[b]{2}{*}{ Patient } & \multirow[b]{2}{*}{ Age } & \multirow[b]{2}{*}{ Sex } & \multirow[b]{2}{*}{$\begin{array}{l}\text { Age of } \\
\text { epilepsy onset }\end{array}$} & \multicolumn{2}{|l|}{ Seizure } & \multirow[b]{2}{*}{$\begin{array}{l}\text { Concomitant anti- } \\
\text { convulsant treatment }\end{array}$} \\
\hline & & & & Type & $\begin{array}{l}\text { Frequency } \\
\text { per month }\end{array}$ & \\
\hline 1 & 63 & $\mathbf{F}$ & 28 & \multirow{4}{*}{$\begin{array}{l}\text { Complex } \\
\text { partial } \\
\text { Complex } \\
\text { partial } \\
\text { Complex } \\
\text { partial } \\
\text { Complex } \\
\text { partial }\end{array}$} & 1 & \multirow{2}{*}{$\begin{array}{l}\text { phenytoin } \\
\text { primidone } \\
\text { primidone }\end{array}$} \\
\hline 2 & 45 & $\mathbf{F}$ & 25 & & 8 & \\
\hline 3 & 37 & $\mathbf{F}$ & 6 & & 6 & \multirow{4}{*}{$\begin{array}{l}\text { carbamazepine } \\
\text { clobazam } \\
\text { oxcarbazepine } \\
\text { sodium valproate } \\
\text { diazepam } \\
\text { sodium valproate } \\
\text { clobazam } \\
\text { carbamazepine } \\
\text { clobazam }\end{array}$} \\
\hline 4 & 38 & $\mathbf{M}$ & 15 & & 6 & \\
\hline 5 & 19 & $\mathbf{M}$ & 14 & \multirow{2}{*}{$\begin{array}{l}\text { Complex } \\
\text { partial } \\
\text { Myoclonic }\end{array}$} & 16 & \\
\hline 6 & 36 & $\mathbf{M}$ & 16 & & 10 & \\
\hline
\end{tabular}

* Seizure frequency in the month prior to starting vigabatrin. dopamine (DA) systems. We report on the effect of vigabatrin on binding of ${ }^{123} \mathrm{I}$ labelled $\mathrm{S}(-)-\mathrm{N}-[(1-$-ethyl-2-pyrrolidinyl)methyl]2-hydroxy-3-iodo-6-methoxybenzamide (IBZM) to striatal D2 receptors, measured using single photon emission tomography (SPET).

\section{Patients and methods}

Six patients with chronic epilepsy resistant to treatment entered the study. All gave their informed consent. Five of the subjects were right handed. Five patients suffered from partial epilepsies but in only two cases did EEG investigation identify a likely epileptic focus. In both patients, this was in the right posterior temporal region. Other characteristics of the patients are described in table 1.

At the start of the investigation each patient underwent their first SPET scan. The following day vigabatrin was commenced, taken in addition to the pre-existing and unchanging anticonvulsant regimen. The starting dose of vigabatrin was $0.5 \mathrm{~g}$ twice daily. This increased by $1 \mathrm{~g}$ a week over the next two weeks to a final dose of $1.5 \mathrm{~g}$ twice daily. Four weeks after the first scan the patients were rescanned in identical circumstances.

The radiopharmaceutical drug used was ${ }^{123}$ I-IBZM supplied by Cygne B.V., University of Eindhoven, The Netherlands. Patients received a mean dose of $5 \mathrm{mCi}(185 \mathrm{MBq})$ for each scan. The tracer was given through a 19 gauge cannula placed in the right antecubital vein. The ${ }^{123}$ I-IBZM was flushed through the cannula with $20 \mathrm{ml}$ of saline $(0.9 \%)$. The injection procedure took about 20 seconds. The patients experienced no side effects immediately following injection of the tracer or subsequently.

The scans were performed in a brain dedicated, single slice tomographic scanner (SME 810 Brain Tomograph: Strichman Medical Equipment) at the Institute of Nuclear Medicine. Each patient was placed supine with the head in the centre of the detection hole in the gantry and positioned for scanning $30-40 \mathrm{~mm}$ above the orbitomeatal line. The patient was silent with eyes closed. After resting quietly for 1-2 minutes the patient then received the intravenous injection of ${ }^{123}$ I-IBZM. Over the following two hours 20 images were taken at this position with the acquisition time of five minutes each. Slices were consequently reconstructed with an axial thickness of $2.5 \mathrm{~cm}$. The in-plane resolution of the system was $7 \mathrm{~mm}$ full width at half maximum. 
Mean specific and nonspecific binding in left and right basal ganglia (BG) and frontal cortex (FC) before introduction of vigabatrin $(n=6)$

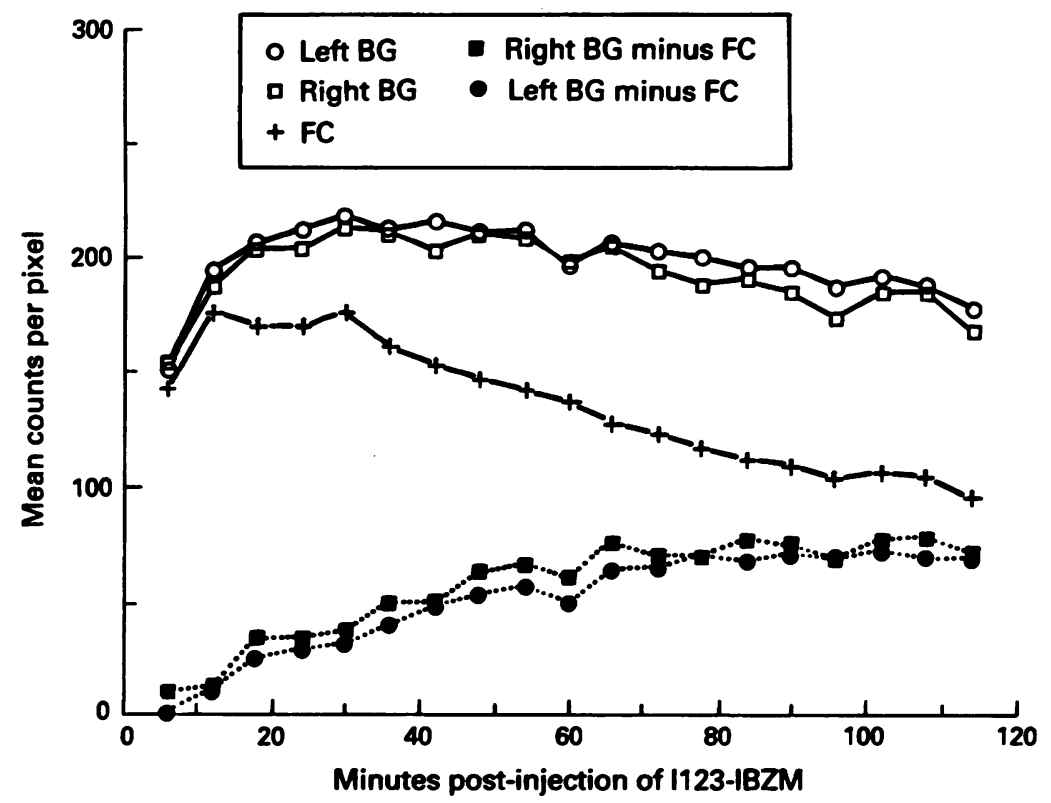

Figure Mean specific and non-specific binding in left and right basal ganglia (BG) and frontal cortex $(F C)$ before introduction of vigabatrin $(n=6)$.

\begin{abstract}
Results
Images were reconstructed and analysed using software provided by SME. A region of interest analysis was performed. Left and right basal ganglia regions were defined as those regions visualised using the $70 \%$ isocolour contour on the image that provided optimal regional clarity (usually the image taken around 110 minutes). Left and right frontal regions were combined and a region was drawn around the area corresponding to frontal cortex as optimally displayed, usually on the 10 minute image, at the $40 \%$ isocolour contour.

A measure of the striatal activity due to specific ${ }^{123}$ I-IBZM binding may be obtained by subtracting the activity in the frontal cortex from left and right basal ganglia activity. ${ }^{10}$ The mean time-activity distributions obtained in 19 images acquired over two hours following injection of the ligand in the six subjects during their pre-vigabatrin scan are shown in the figure.
\end{abstract}

Table 2 Mean basal ganglia to frontal cortex activity ratios

\begin{tabular}{|c|c|c|c|c|}
\hline \multirow[b]{2}{*}{ Image (min) } & \multicolumn{2}{|c|}{ Mean ratio of right $B G / F C$} & \multicolumn{2}{|c|}{ Mean ratio of left $B G / F C$} \\
\hline & pre-vigabatrin & on vigabatrin & pre-vigabatrin & on vigabatrin \\
\hline $\begin{array}{r}60 \\
66 \\
72 \\
78 \\
84 \\
90 \\
96 \\
102 \\
108\end{array}$ & $\begin{array}{l}(\text { SEM) } \\
1.45(0.06) \\
1.59(0.05) \\
1.56(0.05) \\
1.59(0.05) \\
1.68(0.03) \\
1.67(0.04) \\
1.66(0.04) \\
1.72(0.05) \\
1.75(0.04)\end{array}$ & $\begin{array}{l}\text { (SEM) } \\
1.47(0.04) \\
1.46(0.04) \\
1.49(0.04) \\
1.54(0.04) \\
1.56(0.05) \\
1.56(0.06) \\
1.58(0.05) \\
1.58(0.07) \\
1.62(0.04)\end{array}$ & $\begin{array}{l}\text { (SEM) } \\
1.45(0.08) \\
1.60(0.05) \\
1.63(0.04) \\
1.70(0.04) \\
1.73(0.03) \\
1.77(0.06) \\
1.80(0.02) \\
1.79(0.04) \\
1.78(0.02)\end{array}$ & $\begin{array}{l}\text { (SEM) } \\
1.51(0.06) \\
1.52(0.03) \\
1.55(0.04)^{\mathrm{a}} \\
1.58(0.03)^{\mathrm{b}} \\
1.59(0.05)^{\mathrm{c}} \\
1.63(0.04)^{\mathrm{d}} \\
1.65(0.05)^{\mathrm{e}} \\
1.64(0.05) \\
1.72(0.04)\end{array}$ \\
\hline
\end{tabular}

BG = basal ganglia.

FC = frontal cortex

$\mathrm{FC}=$ frontal cortex.
$\min =$ minutes post-injection.

$\min =$ minutes post-injection.
$\mathrm{SEM}=$ standard error of the mean

$\mathrm{SEM}=$

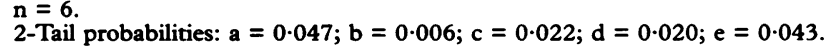

The results of interest to this study were changes in basal ganglia specific binding between the two scans. Our analysis, therefore, investigated changes in the ratios of regional activities in the left and right basal ganglia to frontal cortex. The means of the right basal ganglia to frontal cortex and the left basal ganglia to frontal cortex ratios for the 60 to 110 minute images in each scan were calculated. The values for these nine images were compared for changes between the pre-treatment and the on-treatment scans. Significance was assessed using paired Student $t$ tests. The results are given in table 2 . There are no significant differences between the two conditions for the right basal ganglia. On the left side, however, for five consecutive images, corresponding to approximately 70 to 95 minutes post-injection, vigabatrin treatment was associated with a significant decrease in the ratio of basal ganglia to frontal cortex binding. There were no differences in striatal ${ }^{123} \mathrm{I}-\mathrm{IBZM}$ binding between the two conditions in the first hour post-injection, reflecting the development of specific binding after this time.

To assess the reliability of this analysis, two scans were measured twice and the results compared according to the method suggested by Bland and Altman. ${ }^{11}$ The repeatability coefficient was 6.5 counts a pixel.

\section{Discussion}

To assess the value of these results, several issues should be examined. A number of studies have investigated the value of ${ }^{123}$ I-IBZM as a specific dopamine D2 imaging agent. Labelled IBZM binding to striatal D2 receptors is reversible. Distribution during the first 30 minutes or so after injection represents largely flow-determined non-specific binding in all brain regions. ${ }^{1213}$ As time progresses beyond this, however, non-specific binding decreases and the proportion of specific binding in the basal ganglia increases. ${ }^{14}$ After a further period of time, there is washout of specific binding, underlining the reversibility of ${ }^{123}$ I-IBZM binding. ${ }^{10}$ The results given in the figure demonstrate that a relatively stable plateau of specific binding is reached for data acquired more than 60 minutes post-injection. This finding corresponds to the kinetic study reported by Brucke et $a l^{10}$ and like those authors, we have used the stable period from 60 to 110 minutes post-injection for the rest of our data analysis.

${ }^{123}$ I-IBZM is a D2 receptor antagonist ${ }^{12}$ and binds selectively to these receptors. ${ }^{1315}$ The frontal cortex was chosen as a control area because there is very little specific D2 binding in that region, reflecting a local paucity of these receptors. Specific binding in the basal ganglia has previously been demonstrated by Kung et $\mathrm{al}^{15}$. who compared the binding constant in the basal ganglia of rats where there is a striatal $\mathrm{Bmax}$ (fmol/mg protein) of $480 \pm 22$, to a value of $47 \pm 6.2$ in the frontal cortex. A comparison with the performance of the D2 receptor ligand ${ }^{11} \mathrm{C}$-raclopride validates the use of ${ }^{123} \mathrm{I}$-IBZM for this purpose. The ratio of 
striatal to cerebellar activity in a monkey brain 120 minutes after injection of ${ }^{123}$ I-IBZM was 4.93. This value is very similar to the corresponding ratio observed 20 to 60 minutes after the administration of ${ }^{11} \mathrm{C}$-raclopride to monkeys. ${ }^{16}$ This latter ligand has been widely used with positron emission tomogaphy (PET) to visualise dopamine $\mathrm{D} 2$ receptor binding. ${ }^{17}$

The results of this study indicate that there is a significant decrease in specific binding to left hemisphere striatal D2 receptors after one month of treatment with vigabatrin. One explanation of this decreased binding is that it is associated with increased postsynaptic D2 receptor stimulation associated with increased activity in the left hemisphere nigrostriatal dopamine pathways. This is supported by other reported findings. Innis et $a l^{18}$ have recently demonstrated that in non-human primates, amphetamine-induced endogenous dopamine release may effectively compete with ${ }^{123}$ I-IBZM for in vivo binding to D2 receptors. Similarly, a PET study of the effects of chronic cocaine abuse on postsynaptic dopamine receptors using the labelled D2 receptor ligand $\left[{ }^{18} \mathrm{~F}\right] \mathrm{N}$-methylspiroperidol demonstrated that cocaine abusers who had been detoxified for a week or less showed significantly lower values for uptake of $\left[{ }^{18} \mathrm{~F}\right] \mathrm{N}$-methylspiroperidol in striatum than normal subjects. ${ }^{19}$ Cocaine is known to inhibit neuronal reuptake of dopamine, potentiating its synaptic activity. ${ }^{20}$ These observations have further relevance for the current study since, like vigabatrin, both amphetamine and cocaine not only reduce radioligand binding to striatal D2 receptors, but also occasionally result in the development of paranoid psychotic states in humans. ${ }^{21}$

It is possible that variables within the study population, other than the introduction of vigabatrin, may have accounted for the observed results. The patients were all taking other anticonvulsant medications in addition to vigabatrin. Several of these drugs have effects on central GABAergic receptors. ${ }^{22}$ This fact, however, is not thought to explain our observations since these medications remained unchanged throughout the study. With respect to seizure frequency, an observation period of one month is insufficient to allow any accurate judgement on the efficacy of vigabatrin. In addition, the small number of patients in this study precludes an investigation of the relationship between changes in striatal D2 receptor binding and treatment related variations in seizure frequency. Nevertheless, there appears to be no role for changes in seizures associated with introduction of vigabatrin in explaining our results. Three of the patients had at least a $50 \%$ reduction in seizure frequency during the study, compared to the preceeding month, but the other three failed to show any benefit. This separation was not however reflected by the individual results in the study. Similarly, there was no significant difference in the number of seizures occurring in the three days preceding the two scans. Five patients were right handed. The results from the single left handed patient were not obviously different from this group.

Five of the six subjects suffered partial epilepsy but the laterality of the focus could only be established in two cases. No overall asymmetry of epileptiform activity could be detected that would account for an asymmetric response to vigabatrin.

It is noted that, in both the pre-vigabatrin and the on-vigabatrin scans, there is greater binding of ${ }^{123}$ I-IBZM to the left than to the right basal ganglia. This hemisphere difference cannot be readily explained. There is no evidence that it is related to either the laterality of epileptic foci or to handedness. The changes in binding that are associated with the introduction of vigabatrin appear to be superimposed on this pre-existing asymmetry.

There have been no published studies investigating the possibility of a direct effect of vigabatrin on striatal dopamine receptors. In humans previous work investigating the effect of vigabatrin on cerebral dopamine systems has been limited to CSF measurements of dopamine catabolites. There is some evidence that acute administration may cause increased dopamine release; Ben-Menachem ${ }^{23}$ reported that following a single dose of vigabatrin there was a significant increase in homovanillic acid (HVA) CSF concentration sustained for seven days. Continuing treatment for at least two months, however, HVA levels were found to be similar to baseline concentrations. Riekkinen et $a l,{ }^{24}$ after treating patients with vigabatrin for three months with a daily dose of $3 \mathrm{~g}$ a day, found no change in CSF HVA levels compared to baseline. These findings do not necessarily contradict the results of this study; firstly because in our study patients received their second assessment after four weeks of treatment and prior clinical observations suggested that those who respond to the treatment continue to derive increasing benefit beyond this time. This suggests that in our study a steady state had not yet been reached thus corresponding to the acute changes observed in the study by Ben-Menachem. ${ }^{23}$ Secondly, because it would be necessary to demonstrate that increases in synaptic (DA) concentrations sufficient to result in receptor changes would be detectable.in the CSF.

The mechanism by which vigabatrin could increase activity in the nigrostriatal dopamine system is not yet established. Although descending GABAergic fibres from the striatum and globus pallidus project to the substantia nigra, largely to the reticulata, ${ }^{25}$ little is known of the interactions between these afferents and the dopaminergic efferents leaving the pars compacta in humans. In rats, striatonigral GABAergic neurons project directly to pars compacta DA neurons and also to proposed pars reticulata interneurons. ${ }^{26}$ Striatal stimulation, resulting in increased activity in striatonigral GABAergic projections, has been shown to stimulate pars compacta DA cells. It has been suggested that this follows net disinhibition of these DA cells secondary to preferential inhibition of the inhibitory interneurons which are more sensitive to this effect of GABA. ${ }^{27}$ It is thus possible that vigabatrin acts to increase activity in the nigrostriatal dopamine pathway through its effect on polysynaptic striatonigral 
GABA-GABA-DA systems resulting in net disinhibition of nigral dopamine neurons.

An interesting feature of our results is that the observed effect of decreased specific binding of ${ }^{123} \mathrm{I}-\mathrm{IBZM}$ to striatal $\mathrm{D} 2$ receptors, whilst significant in the left basal ganglia, failed to reach significance on the right side. Although it may be observed from the figures in table 2 that the pattern of uptake changed in a qualitatively similar manner on both sides, there is less effect on the right. Our small sample size of six patients limits the conclusions that can be drawn from the study. Nevertheless, it is noted that at none of the five consecutive time points at which there was a significant decrease in left basal ganglia specific binding whilst on vigabatrin was there such a decrease on the right. Furthermore, a number of studies investigating the laterality of a unilateral epileptic focus in patients with schizophrenia-like psychoses in epilepsy have observed that in the majority of cases the focus was on the left. ${ }^{28}$ This observation taken in conjunction with the findings of the current study may suggest that the left hemisphere nigrostriatal DA system is more sensitive than the right to modulating influences that lead to changes in activity in the dopaminergic pathways.

H A Ring is grateful for the financial support of the Raymond Way Memorial Fund.

1 Ring HA, Reynolds EH. Vigabatrin. In: PedleyT, Meldrum BS, eds. Recent advances in epilepsy 5. London: Churchill BS, eds. Recent advances in

2 Lippert B, Metcalf BW, Jung MJ, Casara P. 4-Amino-hex5 -enoci acid; a selective catalytic inhibitor of 4-aminobutyric-acid aminotransferase in mammalian brain. Eur $f$ Biochem 1977;74:441-5.

3 Jung MJ, Lippert B, Metcalf BW, Bohlen P, Schechter PJ. Gamma-vinyl GABA (4-amino-hex-5-enoic acid), a new selective irreversible inhibitor of GABA-T: effects on brain GABA metabolism in mice. $\mathcal{f}$ Neurochem 1977;29:797-802.

4 Schechter PJ, Hanke NF, Grove J, Huebert N, Sjoerdsma A Biochemical and clinical effects of gamma-vinyl-GABA in patients with epilepsy. Neurology 1984;34:182-6.

5 Sander JWAS, Hart YM, Trimble MR, Shorvon SD. Vigabatrin and psychosis. $\mathcal{f}$ Neurol Neurosurg Psychiatry 1991;54:435-9.

6 Dam M. Vigabatrin and behaviour disturbances. Lancet 1990;335:605.

7 Iadarola MJ, Gale K. Substantia nigra: Site of anticonvulsant activity mediated by gamma-aminobutyric acid. Science 1982;218:1237-40.

8 Parent A, Mackey A, De Bellefeuille L. The subcortica afferents to caudate nucleusand putamen in primate: A fluorescence retrograde double labeling study. Neuroscience 1983;10:1137-50.

9 Trimble MR. Biological Psychiatry. Chichester: John Wiley and Sons, 1988.

10 Brucke T, Podreka I, Angelberger P, Wenger S, Topitz A, Kufferle B, Muller CH, Deecke L. Dopamine D2 receptor imaging with SPET: Studies in different neuropsychiatric disorders. $f$ Cerebral Blood Flow and Metabopsychiatric disorders.

11 Bland JM, Altman DG. Statistical methods for assessing the agreement between two methods of clinical measurement. Lancet 1986;i:307-10.

12 Kung HF, Alavi A, Chang W, Kung MP, Keyes JW, Velchik MG, Billings J, Pan S, Noto $R$, Rausch, et al. In vivo SPECT imaging of CNS D-2 dopamine receptors: initial studies with iodine-123-IBZM in humans. $7 \mathrm{Nucl} \mathrm{Med}$ 1990;31:573-9.

13 Singhaniyom W, Tsai YF, Brucke T, McLellan CA, Cohen RM, Kung HF, Chiueh CC. Blockade of 125I-labeled 3-iodobenzamide (IBZM) to dopamine receptors by D2 3-iodobenzamide (IBZM) to dopamine receptors by

14 Costa DC, Verhoeff NPLG, Cullum ID, Ell PJ, Syed GMS, Barrett J, Palazidou E, Toone B, Van Royen E, Bobeldijk $M$. In vivo characterisation of 3-iodo-6-methoxybenzamide $123 \mathrm{I}$ in humans. Eur $f$ Nucl Med 1990;16:813-6.

15 Kung HF, Pan S, Kung MP, Billings J, Kasliwal R, Reilley $\mathrm{J}$, Alavi $\mathrm{A}$. In vitro and in vivo evaluation of [1231]IBZM: A potential CNS D-2 dopamine receptor imaging agent. f Nucl Med 1989;30:88-92.

16 Farde L, Ehrin E, Eriksson L, Greitz T, Hall H, Hedstrom C-G, Litton J-E, Sedvall G. Substituted benzamides as ligands for visualization of dopamine receptor binding in the human brain by positron emission tomography. Proc Natl Acad Sci 1985;82:3863-7.

17 Farde L, Hall H, Ehrin E, Sedvall G. Quatitative analysis of D2 dopamine receptor binding in the living human brain by PET. Science 1986;231:258-61.

18 Innis RB, Malison R, Al-tikriti M, Sybirska E, Zoghbi $S$, Baldwin RM, Smith E, Elsworth J, Kung HF, Alavi A, Hoffer PB, Roth RH. Amphetamine-induced dopamine release competes in vivo for I-123 IBZM binding to dopamine D2 receptors in non-human primate brain. $f$ Nucl Med 1991;32:1007-8.

19 Volkow ND, Fowler JS, Wolf AP, Schlyer D, Shiue C-Y, Alpert R, Dewey SL, Logan J, Bendriem B, Christman D, Hitzemann R, Henn F. Effects of chronic cocaine abuse on postsynaptic dopamine receptors. Am $\mathcal{f}$ Psychiatry 1990;147:719-24.

20 Galloway MP. Neurochemical interactions of cocaine with dopaminergic systems. TIPS 1988;9:451-4.

21 Jaffe J. Drug addiction and drug abuse. In: Gilman AG, Rall TW, Nies AS, Taylor P, eds. The pharmacological basis of theraputics. New York: Pergamon Press, 1990:522-73.

22 Engel J Jr. Seizures and epilepsy. Philadelphia: F.A. Davis Company, 1989:411-2.

23 Ben-Menachem E, Persson LI, Schechter PJ, Haegele KD, Huebert N, Hardenberg J, Dahlgren L, Mumford JP. The effect of different vigabatrin treatment regimens on CSF biochemistry and seizure control in epileptic patients. $B r$ f Clin Pharmac 1989;27(Suppl 1):79S-85S.

24 Riekkinen PJ, Pitkanen A, Ylinen A, Sivenius J, Halonen T. Specificity of vigabatrin for the GABAergic system in human epilepsy. Epilepsia 1989;30(Suppl 3):S18-S22.

25 Graybiel AM. Neurotransmitters and neuromodulators in the basal ganglia. TINS 1991;13:244-54.

26 Grace AA, Bunney BS. Paradoxical GABA excitation of nigral dopaminergic cells: indirect mediation through nigral dopaminergic cells: indirect mediation through 1979;59:211-8.

27 Grace AA, Bunney BS. Opposing effects of striatonigral feedback pathways on midbrain dopamine cell activity. Brain Res 1985;333:271-84

28 Trimble MR. The psychoses of epilepsy. New York: Raven Press, 1991:145-9. 